\title{
Spatial variation of metal bioaccumulation in the hydrothermal vent mussel Bathymodiolus azoricus
}

\author{
Richard P. Cosson ${ }^{a}$, *, Éric Thiébaut ${ }^{b}$, Rui Company ${ }^{c}$, Maryse Castrec-Rouelle ${ }^{d}$, Ana \\ Colaço $^{\mathrm{e}}$, Inês Martins ${ }^{\mathrm{e}}$, Pierre-Marie Sarradin ${ }^{\dagger}$ and Maria João Bebianno ${ }^{\mathrm{c}}$
}

\footnotetext{
a ISOMer-Laboratoire de Biologie Marine, Faculté des Sciences et Techniques, Université de Nantes, BP 92 208, ISOMer - EMI, EA 2663, F-44322 Nantes cedex 3, France

${ }^{b}$ Université Pierre et Marie Curie-Paris6, UMR-CNRS-7144, F-29682 Roscoff cedex, France

${ }^{\mathrm{c}}$ Universidade do Algarve, CIMA, Campus de Gambelas, P-8000 Faro, Portugal

d Université Pierre et Marie Curie-Paris6, UMR 7618 BioEMCo, F-75252 Paris cedex 05, France

e Universidade dos Açores, IMAR/DOP, P-9901-862 Horta, Portugal

${ }^{\dagger}$ Ifremer, Centre de Brest, DEEP LEP, F-29280 Plouzané, France
}

\author{
*: Corresponding author : R. P. Cosson, ISOMer-Laboratoire de Biologie Marine, Faculté des Sciences \\ et Techniques, Université de Nantes, France. tel.: +33 251125 669; fax: +33 251152668. \\ Email address: $\underline{\text { Richard.Cosson@univ-nantes.fr }}$
}

\begin{abstract}
:
The variability of the bioaccumulation of metals $(\mathrm{Ag}, \mathrm{Cd}, \mathrm{Cu}, \mathrm{Fe}, \mathrm{Mn}, \mathrm{Zn})$ was extensively studied in the mussel Bathymodiolus azoricus from five hydrothermal vent sites inside three main vent fields of increasing depth along the Mid Atlantic Ridge: Menez-Gwen, Lucky-Strike and Rainbow. Metal bioaccumulation varied greatly between vent fields and even between sites inside a vent field with $B$. azoricus showing a great capacity to accumulate metals. The bioaccumulation of these metals also varied significantly among tissues. The main target was the gills where metals were mainly associated with soluble compounds whereas in the digestive gland they were mainly associated with insoluble compounds. Storage of metals under insoluble forms in B. azoricus seems to be a major pathway for the detoxification of both essential and non-essential metals. Mussels from the studied fields can be discriminated following their metallic load but the segregation relies partially on the composition of the metal-enriched fluids.
\end{abstract}

Keywords: Bioaccumulation; Metals; Azores; Hydrothermal Vents; Mytilids; Bathymodiolus 


\section{Introduction}

Marine molluscs have a large capacity to accumulate metals and therefore are commonly suggested as biomonitors of metal contamination of marine ecosystems (Phillips, 1977, 1985; Goldberg et al., 1978; Rainbow, 1995; Lauenstein and Daskalalis, 1998; Langston and Bebianno, 1998; Neff, 2002). Some metals $(\mathrm{Cu}, \mathrm{Fe}, \mathrm{Mn}$ and $\mathrm{Zn})$ are essential for living organisms as they are components of enzymes, respiratory proteins and structural elements of organisms. Although they become toxic when present in excess, it has been shown that the coastal mussel, Mytilus edulis, regulates zinc and partially copper bioaccumulation over a wide range of concentrations in the environment sea water (Langston et al., 1998). Conversely, other metals like $\mathrm{Ag}$ and $\mathrm{Cd}$, are non essential metals, their accumulation by molluscs is almost universally determined by the degree of exposure (Langston et al., 1998). The cellular detoxification of trace metals is then achieved by several mechanisms including their binding to metallothioneins (e.g. $\mathrm{Ag}, \mathrm{Cd}, \mathrm{Cu}, \mathrm{Hg}$ and $\mathrm{Zn}$ ) and/or their incorporation to metabolically inert granules (Dallinger and Rainbow, 1993).

The hydrothermal environments are characterized by high concentrations of several metals like $\mathrm{Cd}$, $\mathrm{Cu}, \mathrm{Fe}, \mathrm{Hg}, \mathrm{Mn}, \mathrm{Zn}$ originating from the discharge of hydrogen sulfide-rich vent waters (Corliss et al., 1979; Von Damm, 1990). These peculiar ecosystems represent natural laboratories for studies on the potential deleterious effects of the cited metals (Cosson and Vivier, 1995; Cosson and Vivier, 1997; VENTOX, 2003). Bivalve molluscs living in these environments are known to accumulate tremendous amounts of metals with surprinsingly no evident deleterious effects. Bioaccumulation was reported for the clams Calyptogena magnifica (Roesijadi and Crecelius, 1984; Roesijadi et al., 1985; CossonMannevy et al., 1988) and Vesicomya gigas (Ruelas-Inzunza et al., 2003), and an unidentified Japanese clam (Kim et al., 1991) from the East Pacific Rise. Similar results were obtained when studying the mussels Bathymodiolus thermophilus from the East Pacific Rise (Smith and Flegal, 1989; Rousse, 1999) and B. azoricus from the Mid-Atlantic Ridge (Geret et al., 1998; Rousse et al., 1998).

The Mytilidae of the genus Bathymodiolus are almost ubiquitous among the organisms associated with hydrothermal vents (Tunnicliffe, 1991) and are appropriate models for assessing the responses to the metallic enrichment of such ecosystems. The Atlantic species B. azoricus is commonly found at the Azores Triple Junction hydrothermal vents on the Mid-Atlantic Ridge (ATJ-MAR) where it is frequently the dominant species, extended in high densities at the base or even on the entire walls of the chimneys (Van Dover et al., 1996; Colaço et al., 1998; Desbruyères et al., 2001). Preliminary results from individuals sampled at two sites indicated that the levels of some elements (i.e. Ag, Ba, $\mathrm{Cd}, \mathrm{Cu}, \mathrm{Fe}, \mathrm{Mn}, \mathrm{Sr}$ and $\mathrm{Zn}$ ) within the gills and the digestive gland were high compared to the levels measured in tissues of the mussel Mytilus edulis (Rousse et al., 1998). Moreover, the authors suggested that the observed differences between the levels of metals in the mussels from the two vent sites could be related to differences within the chemical composition of respective hydrothermal fluids. This paper details the bioaccumulation of essential ( $\mathrm{Cu}, \mathrm{Fe}, \mathrm{Mn}$ and $\mathrm{Zn}$ ) and non-essential metals (Ag and $\mathrm{Cd}$ ) in three tissues (i.e. gills, mantle and digestive gland) of $B$. azoricus sampled at five sites located among three different vent fields from the ATJ-MAR. The aims of this study were, (i) to describe the variations of metal levels between tissues, (ii) to address their intracellular distribution between soluble and insoluble fractions in relation with bioaccumulation and detoxification processes, and (iii) to establish an eventual correlation between their abundance within and among vent fields and their bioaccumulation by $B$. azoricus.

\section{Materials and Methods}

\subsection{Sampling and sample preparation}

Mussels were collected during dives using the Ifremer Remotely Operated Vehicule "Victor6000" during the "ATOS 2001" cruise. Three vent fields were explored located on three segments of the south-eastern limb of the ATJ (Ondréas et al. 1997): Menez Gwen (MG, $37^{\circ} 51^{\prime} \mathrm{N}, 31^{\circ} 31^{\prime} \mathrm{W}, 850 \mathrm{~m}$ ), Lucky Strike (LS, $\left.37^{\circ} 17^{\prime} \mathrm{N}, 32^{\circ} 16^{\prime} \mathrm{W}, 1650 \mathrm{~m}\right)$ and Rainbow $\left(36^{\circ} 13^{\prime} \mathrm{N}, 33^{\circ} 54^{\prime} \mathrm{W}, 2350 \mathrm{~m}\right)$ (Fig. 1).

The vent fields differ by their depth (850 to $2350 \mathrm{~m})$, their tectonic settings, the composition of their host rocks (mantle-derived serpentinized peridotite vs. basalt), the nature of associated volcanism, 
their fluid composition and the dominance of different key faunal assemblages (Fouquet et al. 1998, Desbruyères et al. 2001). Samples were collected using the grab of the submersible. Two sites were visited at Menez Gwen (ATOS 8 - A8 and ATOS 10 - A10, North East of the top of the volcano), two at Lucky Strike (Eiffel Tower - ET and Bairro Alto - BA, respectively South East and North West of the lava lake) and one in Rainbow (Rb).

At each site, about ten mussels of comparable size (A8: $4.76 \pm 0.15 \mathrm{~cm}$, A10: $4.99 \pm 0.37 \mathrm{~cm}$, BA: 7.67 $\pm 0.66 \mathrm{~cm}, \mathrm{ET}: 6.50 \pm 0.38 \mathrm{~cm}, \mathrm{Rb}: 6.76 \pm 0.57 \mathrm{~cm}$ ) were sampled from a very small area delimited by a $50 \times 50 \mathrm{~cm}$ frame deployed by the submersible. Mussels were dissected on board. Tissues (i.e. gills, mantle and digestive gland) were isolated, stored in liquid nitrogen and lyophilised when back to the laboratory. Each sample was weighed, homogenized in TRIS buffer $(100 \mathrm{mM}, 10 \mathrm{mM}$ ßmercapthoethanol, $\mathrm{pH} 8.6)$ and centrifuged $\left(30000 \mathrm{~g}, 30 \mathrm{~min}, 4^{\circ} \mathrm{C}\right)$. For each sample, the pellet containing the insoluble compounds (named insoluble fraction hereafter) and an aliquot of the supernatant, containing the soluble compounds (named soluble fraction hereafter) were digested with nitric acid at $60^{\circ} \mathrm{C}$ for metal analysis.

\subsection{Analytical procedure}

Metal quantification (i.e. $\mathrm{Ag}, \mathrm{Cd}, \mathrm{Cu}, \mathrm{Fe}, \mathrm{Mn}$ and $\mathrm{Zn}$ ) was determined by Electrothermal Atomic Absorption Spectrometry (E-AAS: Hitachi Z-5000 and Solaar Unicam 989QZ), by Flame Atomic Absorption Spectrometry (F-AAS: Hitachi Z-5000) or by Inductive Coupled Plasma Atomic Emission Spectrometry (ICP-AES JY-238 sequential) depending on the ratio, concentration vs volume, of the liquid aliquots. The accuracy of the analytical procedure was checked using certified reference material (TORT-2; DORM-2; DOLT-2) from the National Research Council, Canada. Our results were in good agreement with the certified values except for $\mathrm{Ag}$. The concentration of $\mathrm{Ag}$ in the nitric digested supernatants (soluble fractions) of homogenized reference material was too close to our detection limit. The levels of metals are expressed as $\mu \mathrm{g} g-1$ dry weight of soft tissue.

\subsection{Statistical analysis}

In a first step, univariate analyses were performed to assess the variations in the levels of metals among sites for each tissue. One-way ANOVAs with site as a fixed factor were used on logtransformed data $[\ln (x+1)]$. Normality was judged by normal probability plots and homogeneity of variances was verified with the Bartlett's test $(\alpha=0.05)$. Post-hoc comparison tests for means were made using the Tukey's honestly significant difference method for unequal sample size. When a log transformation failed to meet ANOVA assumptions, raw data were analysed by a Kruskal-Wallis nonparametric test. Nonparametric multiple comparisons were performed using Nemenyi and Dunn's test (Zar, 1999). Analyses were carried out on total levels of each metal.

In a second step, principal components analysis (PCA) was used to investigate the spatial patterns of the relative levels of soluble and insoluble fractions of metals over the individuals (Legendre and Legendre, 1998). One analysis was performed for each tissue. Metal levels were $\ln (x+1)$ transformed prior to analysis.

\section{Results}

\subsection{Whole metal levels}

Detailed variations of metal bioaccumulation in the tissues between vent fields and sites are given in Table 1.

\subsubsection{Intra-site comparison}

At Menez Gwen, the gills and the digestive gland showed a similar pattern regarding the mean levels of analysed metals (Table 1). Ag, Cd and Mn levels were higher at ATOS 8 (A8) than at ATOS 10 
(A10), while the contrary was observed for $\mathrm{Cu}$. No significant difference was noticed for Fe and $\mathrm{Zn}$. Concerning the mantle, a pattern similar to that of the gills and digestive gland was observed for $\mathrm{Cu}$ and $\mathrm{Fe}$, while similar levels of $\mathrm{Ag}, \mathrm{Cd}$ and $\mathrm{Mn}$ were measured in mussels from $\mathrm{A} 8$ or $\mathrm{A} 10$. Consequently, with the exception of $\mathrm{Cu}$, tissues of mussels from $\mathrm{A} 8$ presented metal levels (e.g., Ag, $\mathrm{Cd}, \mathrm{Fe}, \mathrm{Mn}, \mathrm{Zn}$ ) higher than or equal to those observed for mussels from A10.

At Lucky Strike, the levels of $\mathrm{Ag}$ in the gills and the mantle were higher at Bairro Alto (BA) than at Eiffel Tower (ET). Higher levels of $\mathrm{Cd}$ and $\mathrm{Zn}$ were observed respectively for the gills and the mantle of mussels collected at BA. Beside these observations, no significant difference was evidenced between the levels of metals measured in gills and mantle from BA or ET mussels.

\subsubsection{Inter-sites comparison}

In general, mean levels of $\mathrm{Ag}, \mathrm{Cd}, \mathrm{Cu}$ and $\mathrm{Zn}$ in mussel tissues were higher at both sites of MG than at Rainbow or did not differ significantly (Table 1). Conversely, Fe and Mn were more abundant in mussels from $\mathrm{Rb}$ than from MG sites.

Similarly mussels collected at $\mathrm{Rb}$ generally contained less $\mathrm{Ag}, \mathrm{Cd}, \mathrm{Cu}$ and $\mathrm{Zn}$ than those collected at LS. The digestive gland was the only tissue where higher levels of Fe and $\mathrm{Mn}$ were observed for mussels collected at $\mathrm{Rb}$.

Gills and mantle of mussels from both BA and A8 presented similar high levels of Ag, while this metal was less abundant in mussels collected at both A10 and ET. Cd was more abundant in the tissues of the mussels collected at LS than in those collected at MG. Cu was particularly abundant in mussels collected at A10 whereas Zn was more abundant in mussels collected at LS, especially at BA. The same observation goes for Fe and Mn with equal mean levels observed for BA and ET in the gills and the mantle.

Mussels from $\mathrm{Rb}$ bioaccumulated more $\mathrm{Fe}$ and Mn than those from MG or LS. Conversely, they showed lower mean levels of $\mathrm{Ag}, \mathrm{Cd}, \mathrm{Cu}$ and $\mathrm{Zn}$. Higher levels of $\mathrm{Cd}, \mathrm{Zn}, \mathrm{Fe}$ and $\mathrm{Mn}$ were recorded for mussels collected at LS than for those collected at MG. At both fields (LS and MG) high levels of Ag were observed in mussels from BA and A8, while the highest level of $\mathrm{Cu}$ was recorded in mussels from A10 site.

\subsection{Metal compartmentalization}

The amount (expressed as percentages - mean values) of metals associated with insoluble compounds in the tissues of mussels collected at the studied ATJ sites are given in Table 2. This amount ranges between 24 and 97\%. However, with a few exceptions (bold in the table), whatever the site, the tissue and the metal, there is a predominant association of the metals with insoluble compounds with mean amounts $>50 \%$.

From all the metals traced at the mussel gills, $\mathrm{Zn}$ was the only one that was not predominantly associated with insoluble compounds, being equally distributed between the soluble and insoluble fractions in mussels from MG and $\mathrm{Rb}$.

In the mantle $\mathrm{Ag}$ is preferably immobilized as soluble form with the exception of mussels from Eiffel Tower site (Lucky Strike field), the ratio of Ag stored under insoluble form of which reached $50 \%$. Cd was essentially associated with insoluble compounds in ATJ mussels. The ratio of $\mathrm{Cu}$ associated with insoluble compounds was low in mussels from Rb, while it was high for MG and LS mussels. Fe and $\mathrm{Mn}$ insoluble percentages were high for ATJ mussel mantles with the exception of Mn at MG. The percentage of $\mathrm{Zn}$ associated with insoluble compounds in mussels from Rb was lower than that of MG and LS mussels.

The association of $\mathrm{Ag}$ with insoluble compounds varied greatly in the digestive gland of mussels from ATJ sites resulting in the following ranking $L S>M G>R b$. Cd was essentially associated with insoluble compounds in mussels from MG and LS, while the association was moderate at Rb. The same observations fit with the association of $\mathrm{Cu}$ and $\mathrm{Zn}$. Similarly, the ratios of $\mathrm{Fe}$ and $\mathrm{Mn}$ immobilized as insoluble form in the digestive gland were elevated.

\subsection{PCA analysis}

A principal components analysis (PCA) was used to investigate the spatial patterns of the relative levels of soluble and insoluble fractions of metals over the individuals. For each tissue, principal 
component analyses clearly separated individuals between the sampling vent fields and even between the vent sites within a field according to their relative concentrations in the soluble and insoluble fractions of the different metals (Fig. 2-4).

The first 2 principal components accounted for $64.2 \%$ of the variability in the metal concentrations in the gill, with $38.9 \%$ on axis 1 and $25.3 \%$ on axis 2 (Fig. 2A). Several groups of mussels were discriminated. Going from the right of axis 1 we found LS mussels (BA then ET) followed by MG mussels (A8 and $\mathrm{A} 10$ ) and $\mathrm{Rb}$ mussels towards the left. This axis discriminates according to the relative levels of $\mathrm{Zn}$ and $\mathrm{Cd}$, insoluble $\mathrm{Ag}$ and $\mathrm{Fe}$, and soluble Mn (Fig. 2B). On the second axis, MG discriminated itself from $\mathrm{Rb}$ and LS vent fields with respect to relative levels of Fe, insoluble $\mathrm{Mn}$ and soluble $\mathrm{Cu}$.

In the mantle, the PCA showed that the first two axes accounted for $64.6 \%$ of variability between the mussels, with $36.2 \%$ explained by axis 1 and $28.4 \%$ by axis 2 (Fig. 3A). The first axis takes into account the relative levels of $\mathrm{Cd}$ and $\mathrm{Fe}$, soluble $\mathrm{Zn}$ and insoluble $\mathrm{Mn}$, while the second one discriminates positively the $\mathrm{Cu}$ levels and negatively the levels of Mn. LS (BA then ET) and MG (A8 and A10) separated out to the right and left of axis 1, respectively (Fig. 3B). Rainbow showed some separation from MG along the second axis.

Axes 1 and 2 of the PCA accounted for $72.8 \%$ of the variability in metal levels in the digestive gland between individuals, with $50.3 \%$ on axis 1 and $22.5 \%$ on axis 2 (Fig. 4A). Metals with the greatest influence on variability between groups of mussels along axis 1 are $\mathrm{Zn}$, soluble $\mathrm{Mn}$ and $\mathrm{Ag}$, and insoluble $\mathrm{Cu}$ (Fig. 4B). Along axis 2 the discrimination follows the levels of insoluble Fe and $\mathrm{Mn}$. On the first plane PCA ordination, Rb separated out from LS and MG along axis 1, while this later field separated from LS and $\mathrm{Rb}$ along axis 2 .

The main features that can be extracted from the 3 PCA are: (i) there is a clear spatial segregation in the metal bioaccumulation by $B$. azoricus; (ii) this site segregation is observed for the 3 organs studied; (iii) the behaviour of each metal or metal fraction is different for each organ studied.

\section{Discussion}

Hydrothermal fluids contain high concentrations of metals, the proportions of which vary greatly from one field to another, even at the scale of the ATJ zone (Charlou et al., 2000, 2002; Douville et al., 2002). These variations are related both to the chemical composition of the basement rocks, the dynamic specificity of each hydrothermal field (Bonatti, 1984; Von Damn 1990) and even the depth bringing about phase separation processes (Charlou et al., 2000, 2002; Douville et al., 2002). Vent mussels do not live directly in contact with the potentially harmful hot fluid but in the highly chemically reactive mixing zone. Here, the mineral-rich solution, characterized by elevated methane, hydrogen and reduced sulfides, mixes dynamically with the bottom oxygen-rich seawater. Metals present in the fluid form precipitates with sulfide in plumes, chimney or in conduits surfaces (Trefry and Trocine, 1985; Von Damm et al., 1995b). Iron forms preferentially fine grained sulfide particles that are exported in the buoyant and neutrally buoyant plume. $\mathrm{Cu}$ and $\mathrm{Zn}$ sulfides form large sized grains and more crystalline particles that settle rapidly in the near field region (Feely et al., 1994).

The bioaccumulation of metals in the mussels depends on the abundance and the bioavailability of the latter in their proximal environment. Moreover, metal bioaccumulation and storage forms are governed by the physiological functioning of the mussels. Taking into account these abiotic and biotic factors, the goal of our work was to ascertain if the amounts of metals bioaccumulated by the vent mussel $B$. azoricus in its tissues reflect the relative abundance of the metals present in the emitted fluids at 5 sites (A8, A10, ET, BA, Rb) located within 3 hydrothermal fields (Menez Gwen, Lucky Strike and Rainbow).

Our results highlighted that vent mussels bioaccumulate higher metal levels ( $\mathrm{Ag}, \mathrm{Cd}, \mathrm{Cu}, \mathrm{Fe}, \mathrm{Mn}, \mathrm{Zn}$ ) in their tissues (gills, mantle, digestive gland) than the coastal mussels, Mytilus edulis (Fung et al., 2004) and M. galloprovincialis (Bebianno and Machado, 1997; Besada et al., 2002; Kalpaxis et al., 2004; Szefer et al., 2004) in similar tissues. These results are in accordance with scattered studies that reported whole levels of various metals in B. azoricus from the same fields (Rousse et al., 1998; Geret et al., 1998; Kadar et al., 2005; Colaço et al., 2006). As a general rule, there are specific pathways of metal bioaccumulation in tissues depending upon their direct contact with the surrounding environment, the bioavailability (chemical forms) of metals, the efficiency of uptake, storage, transfer to inner organs, excretion mechanisms and physiological status. Despite its very peculiar environment and physiology $B$. azoricus presents a metal organotropism similar to the main trends observed in 
coastal mussels (Langston and Bebianno, 1998). The gills are directly exposed to dissolved and particulate metals and show the highest levels of metals while the mantle, similarly exposed, shows the lowest levels. This discrepancy could be related to a lesser involvement of the mantle in exchanges, its participation to shell production as well as storage and its lack of symbionts. The digestive gland of $B$. azoricus is supposed to be involved at a lesser degree in the nutrition owing to the importance of the symbiosis as a source of energy, but confirms its participation in metal metabolism as a pathway and storage organ. However, the fact that $B$. azoricus can thrive with such metallic loads is noteworthy knowing that non essential metal presence or excessive amounts of essential metals result generally in the perturbation of the enzymatic functions (via constitutive ion substitutions on metalloenzymes) and the antioxidant defence system (Bebianno et al., 2005; Company et al., 2006).

A comparison of the levels of studied metals in B. azoricus whole organs was established with data regarding vent bivalves from the East Pacific Rise (EPR): Bathymodiolus thermophilus and two vesicomids Calyptogena magnifica and Vesicomya gigas to assess the metal load of $B$ azoricus (Fig. 5).

Main features emerge from this comparison between $B$. azoricus and related species from the Pacific vents. The high load of $\mathrm{Fe}$ and $\mathrm{Zn}$ in the gills of mussels collected at Rb and LS, respectively has to be attributed to the high concentration of these metals in corresponding end-members (Charlou et al., 2000, 2002; Douville et al., 2002). However it should be noticed that, even though Fe and Zn are as abundant in the fluids from the EPR (Michard et al., 1984; Von Damm, 1995; Cosson 1996; Le Bris et al., 2003) than in Rb and LS fluids, the availability of both metals in the surrounding environment of $B$. thermophilus seems to be lower than in $B$. azoricus environment (Table 3). Conversely, $\underline{C}$. magnifica and $\underline{\mathrm{V}}$. gigas, present high levels of $\mathrm{Fe}$ and $\mathrm{Zn}$. Several hypothesis can be proposed to explain this

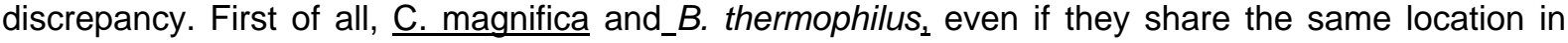
some EPR sites, are not positioned identically with regard to the emission of the fluid-seawater mixture. C. magnifica lives in cracks in the basalt crust with its foot extending towards the input of fluid enriched with reduced compounds, while $B$. thermophilus is an epibiotic organism living on bare basalt having a more versatile relationship to the reduced compound-providing fluid. In the Guaymas Basin, $V$. gigas is encountered in a sedimentary environment enriched with particulate mineral and organic matter which could be ingested and partially responsible for the important metal bioaccumulation (Ruelas-Inzunza et al., 2003). The high amounts of $\mathrm{Zn}$ in C. magnifica tissues could also be attributed to the occurrence of a $\mathrm{Zn}$-protein involved in sulphide transport from their foot to the endosymbiont host in their gills (Childress et al., 1993). The existence of such a protein has been suggested by Ruelas-Inzunza et al. (2003) as a reason for the high amounts of $\mathrm{Zn}$ observed in $V$. gigas tissues. Moreover, the degree of dependence of the bivalve genus regarding their endosymbionts could interfere with the uptake of metals from their environment under soluble or particulate forms, in relation with their feeding habit. Copper in the end-member and immediate neighbourhood of mussels at MG is low compared to recorded values for the EPR or LS and Rb sites (Charlou et al., 2000, 2002; Cosson 1996; Douville et al., 2002; Michard et al., 1984; Von Damm, 1995), but however Cu is abundant in both gills and mantle of MG mussels reflecting a higher bioavailability.

The association of $\mathrm{Ag}$ with insoluble compounds in the gills of $B$. azoricus is less important than for $B$. thermophilus but similar to that observed in $M$. edulis. Mussels from LS are presenting intermediate values (Table 2). Conversely, the storage of $\mathrm{Cd}$ under insoluble forms is more efficient for $B$. azoricus. It is of interest to note that compared to $M$. edulis both Bathymodiolus species present higher percentages of $\mathrm{Cd}$ associated with insoluble compounds. The proportion of $\mathrm{Cu}$ in an insoluble form in $B$. azoricus is generally lower than the very high value reported for $B$. thermophilus and higher than the intermediate value reported for $M$. edulis. The percentage of insoluble $\mathrm{Zn}$ in the gills of mussels from LS is the highest reported, but mussels from MG or Rb show percentages similar to that reported for $B$. thermophilus_and $M$. edulis.

In the mantle of mussels from ATJ, the proportion of $\mathrm{Ag}$ immobilized in an insoluble form is low compared to the corresponding ratio observed for $B$. thermophilus. Mussels from Rb present a percentage of $\mathrm{Ag}$ bound to insoluble compounds equivalent to that observed in $\mathrm{M}$. edulis mantle, while the values reported for MG and LS mussels are higher. Unlike $B$. thermophilus $C d$ is essentially associated with insoluble compounds in $B$. azoricus mantle. Owing to the very low and erratic levels of $\mathrm{Cd}$ in the mantle of $M$. edulis used as controls in cited metal exposure experiments, no comparison can be established with $B$. azoricus $\mathrm{Cd}$ partitioning. The proportion of $\mathrm{Cu}$ associated with insoluble compounds in $B$. azoricus mantle is generally below that reported for $B$. thermophilus. ATJ mussels present percentages of $\mathrm{Cu}$ associated with insoluble compounds in their mantle equivalent to those 
reported for $M$. edulis. Generally, the association of $\mathrm{Zn}$ with insoluble compounds is more effective in $B$. azoricus than in B. thermophilus or M. edulis.

The percentage of $\mathrm{Ag}$ associated with insoluble compounds in the digestive gland of $\mathrm{Rb}$ mussels is equivalent to that recorded for $M$. edulis, while that observed at MG and LS are higher and much higher, respectively. Mussels from ATJ present a high association of $\mathrm{Cd}, \mathrm{Cu}$ and $\mathrm{Zn}$ with insoluble compounds in the digestive gland compared to $M$. edulis.

In $B$. azoricus the partionning of metals between soluble and insoluble fractions varies among sites and tissues as whole metal levels do. But, as mentioned in earlier work, metals are preferentially associated with insoluble compounds (Rousse et al., 1998; Geret et al., 1998). However it is noticeable that the distribution of metals in $B$. azoricus tissues often does not differ from that of corresponding tissues of non-exposed $M$. edulis, underlying that the compartmentalization of metals in bivalves is a complex phenomenon not directly related to their abundance in the surrounding seawater and/or the whole tissue. The comparison of the proportion of metals stored as insoluble forms in the tissues of both Bathymodiolus species (with higher percentages observed for $\mathrm{Ag}$ and $\mathrm{Cu}$ in $\mathrm{B}$. thermophilus, while higher percentages of $\mathrm{Cd}$ and $\mathrm{Zn}$ are observed in $B$. azoricus) supports also the former statement. Nevertheless, the efficient storage of metals as chemical forms known to be less toxic is a mechanism allowing Bathymodiolus to cope with a highly metal-loaded environment.

The PCA analysis (Fig. 2-4) allows discrimination of the bioaccumulation of metals by $B$. azoricus in relation to the sampling fields (RB, LS and MG) and even to the sampling sites (MG-A8 vs A10, LS-ET vs $\mathrm{BA}$ ). This discrimination can be related to the large differences observed in the chemical composition of the hydrothermal fluids emitted in the 3 fields (Table 3). The fluids venting in Rainbow are characterized by unique $\mathrm{Fe}$ and $\mathrm{Mn}$ composition, largely higher than generally encountered in the MAR hydrothermal vents. This metallic enrichment of the fluid is also observed for $\mathrm{Ag}, \mathrm{Cu}, \mathrm{Zn}$ and $\mathrm{Pb}$ (Douville et al., 2002). In the same way, the discrimination observed at the site scale in Lucky Strike between Eiffel Tower and Bairro Alto can be explained by the differences in end-member concentrations between the vents located around the LS lava lake area (Charlou et al., 2000). Bairo Alto is situated in the Northern part of the lake where the emitted fluids have a salinity similar to seawater. Eiffel Tower is in the Southern part of the lake where the fluid exhibits a salinity lower than seawater. The same conclusion could be applied to Menez Gwen: the two different sampling sites (A8 and A10) are situated in the NW of the volcano and could be under the influence of two chemically different fluids not studied by Charlou et al., 2000.

However, the chemical composition of the pure fluid is not sufficient to explain the discrimination observed in the PCA. For example, concerning gills and mantle, the LS mussels are separated from $\mathrm{Rb}$ mussels owing to their high levels of $\mathrm{Cd}$ and $\mathrm{Zn}$ that are not consistent with data regarding the fluid concentration at LS. In the same way, the variables $\mathrm{Fe}$ and $\mathrm{Mn}$ are often opposed to $\mathrm{Zn}$ and $\mathrm{Cu}$, whereas the metal concentrations in the fluid follow the same trend with higher concentrations at Rainbow and smaller ones in Menez Gwen. Consequently, the metal burden of $B$. azoricus tissues is under the dependency of factors belonging to different scales. At the site scale, the composition of the emitted fluid governs the input of metals in the ecosystem and their potential bioaccumulation by mussels. At the scale of mussel's immediate environment, uptake and storage of metals is more dependent of their physico-chemical forms (dissolved vs particulate), the potential accumulation of particulate matter, their association with inert or organic material, and the physiological needs and behaviour of the mussels. However, even if not directly related to their concentration in the pure fluid, the analysis of the metallic load of $\underline{B}$. azoricus allows their separation among the three studied ATJ fields.

Taking into account that the bioaccumulation of metals in bivalves results mainly from their trophic uptake (e.g. Geret 2000, Wang 2002) the high amounts of metals observed in the mixotrophic $B$. azoricus are surprising. Several explanations can be proposed: (i) B. azoricus are exposed continuously to a metal enriched environment (Desbruyères et al., 2001); (ii) metals in $B$. azoricus surrounding water are in extremely available forms; (iii) $B$. azoricus uptake rates from the environment are extremely high in relation with the need of energy sources; (iv) the trophic uptake of metal by $B$. azoricus is particularly important despite the relevant role of the symbiosis in its nutrition. Data regarding the bioavailability of metals in mussels proximate environment are needed. Further work has to be developed regarding metal uptake pathways, direct or trophic, in relation with the feeding habits of $B$. azoricus and the occurrence of metal containing particles in its digestive tract and the putative participation of symbionts in trace element detoxication in the gills. 


\section{Conclusions}

Our study confirms the existence of an equilibrium between the levels of metals in the end-members, the proximate environment of $B$. azoricus and mussel tissues. The recorded variations are due to local modification of metal bioavailability generated by abiotic or biotic factors, and the physiological status of the organisms influenced by the physico-chemical characteristics of the three studied fields.

\section{Acknowledgements}

We would like to thank the captains and crews of the R/V L'Atalante and ROV Victor and the scientific team for their help. This work was financially supported by the EU Framework 5 programme, Contract $\mathrm{N}^{\circ}$ EVK3-CT19900003 VENTOX. We are endebted to Professors (retired) A. Fiala-Médioni and M. Laulier for a draft version of this article and help during the ATOS 2001 cruise, respectively.

\section{References}

Bebianno, M.J., Machado, L.M., 1997. Concentrations of metals and metallothioneins in Mytilus galloprovincialis along the coast of Portugal. Marine Pollution Bulletin, 34(8), 666-671.

Bebianno, M.J., Company, R., Serafim, A., Camus, L., Cosson, R.P., Fiala-Médioni, A., 2005. Antioxidant systems and lipid peroxidation in Bathymodiolus azoricus from Mid-Atlantic Ridge hydrothermal vent fields. Aquatic Toxicology, 75, 354-373.

Besada, V., Fumega, J., Vaamonde, A., 2002. Temporal trends of $\mathrm{Cd}, \mathrm{Cu}, \mathrm{Hg}, \mathrm{Pb}$ and $\mathrm{Zn}$ in mussel (Mytilus galloprovincialis) from the Spanish North-Atlantic coast 1991-1999. Science of the Total Environment, 288, 239-253.

Bonatti, E., 1983. Hydrothermal metal deposits from the ocean rifts: A classification. In: Rona P.A., Böstrom K., Laubier L., Smith K.L. Jr. (Eds). Hydrothermal Processes at Sea Floor Spreading Centers. Plenum, New York, 491-502 pp.

Charlou, J-L., Donval, J-P., Douville, E., Jean-Bathiste, P., Radford-Knoery, J., Fouquet, Y., Dapoigny, A., Stievenard, M., 2000. Compared geochemical signatures and the evolution of Menez-Gwen $\left(37^{\circ} 50^{\prime} \mathrm{N}\right)$ and Lucky-Stike $\left(37^{\circ} 17^{\prime} \mathrm{N}\right)$ hydrothermal fluids, south of the Azores Triple Junction on the Mid-Atlantic Ridge. Chemical Geology, 171(1-2), 49-75.

Charlou, J-L., Donval, J-P., Douville, E., Fouquet, Y., Jean-Bathiste, P., Holm, N., 2002. Geochemistry of high $\mathrm{H}_{2}$ and $\mathrm{CH}_{4}$ vent fluids issuing from ultramafic rocks at the Rainbow hydrothermal field $36^{\circ} 14^{\prime} \mathrm{N}$, MAR. Chemical Geology, 19(14), 345-359.

Childress, J.J., Fisher, C.R., Favuzzi, J.A., Arp, A.J., Oros, D.R., 1993. The role of a zinc based serum-borne sulphide-binding component in the uptake and transport of dissolved sulphide by the chemoautotrophic symbiont containing clam Calyptogena elongata. Journal of Experimental Biology, 179, 131-158.

Colaço, A., Bustamante, P., Fouquet, Y., Sarradin, P-M., Serrão Santos, R., 2006. Bioaccumulation of $\mathrm{Cu}, \mathrm{Zn}$, and $\mathrm{Hg}$ in the Azores Triple Junction hydrothermal vent fields food chains. Chemosphere, 65, 2260-2267.

Colaço, A., Desbruyères, D., Comtet, T., Alayse, A-M., 1998. Ecology of the Menez Gwen hydrothermal field (Mid-Atlantic Ridge/Azores Triple Junction). Cahiers de Biologie Marine, 39, 237240.

Company, R., Serafim, A., Cosson, R.P., Fiala-Médioni, A., Dixon, D., Bebianno, M.J., 2006. Temporal variation in the antioxidant defence system and lipid peroxidation in the gills and mantle of hydrothermal vent mussel Bathymodiolus azoricus. Deep-Sea Research (Part I), 53, 1101-1106.

Corliss, J.B., Dymond, J., Gordon, L.I., Edmond, J.M., von Herzen, R.P., Ballard, R.D., Green, K., Williams, D., Bainbridge, A., Crane, K., Andel, T.H., 1979. Submarine thermal springs on the Galapagos Rift. Science, 203, 1073-1083.

Cosson, R.P., 1996. La bioaccumulation des minéraux chez le Vestimentifère Riftia pachyptila (Jones): bilan des connaissances. Oceanologica Acta, 19, 163-176.

Cosson, R.P., Vivier, J-P., 1995. Impact of metals on hydrothermal vent communities: Bioaccumulation and detoxication processes. Marine Environmental Research, 39 (1-4), 349.

Cosson, R.P., Vivier, J.P., 1997. Interactions of metallic elements and organisms within hydrothermal vents. Cahiers de Biologie Marine, 38, 43-50. 
Cosson-Mannevy, M.A., Cosson, R.P., Gaill, F., 1988. Transfert, accumulation et régulation des éléments minéraux chez les organismes des sources hydrothermales. Oceanologica Acta, 8, 219-225. Dallinger, R., Rainbow, P., 1993. Ecotoxicology of metals in invertebrates. A Special Publication of SETAC, Lewis Publishers, Boca Raton.

Desbruyères, D., Biscoito, M., Caprais, J-C., Colaço, A., Comtet, T., Crassous, P., Fouquet, Y., Khripounoff, A., Le Bris, N., Olu, K., Riso, R., Sarradin, P-M., Segonzac, M., Vangriesheim, A., 2001. Variations in deep-sea hydrothermal vent communities in the Mid-Atlantic Ridge near the Azores plateau. Deep-Sea Research (Part I), 48, 1325-1346.

Desbruyères, D., Segonzac, M., Bright, M., 2006. Handbook of Deep-Sea Hydrothermal Vent Fauna. Second completely revised edition. Denisia, 18.

Douville, E., Charlou, J-L., Oelkers, E.H., Bienvenu, P., Colon, C.F.J., Donval, J-P., Fouquet, Y., Prieur, D., Appriou, P., 2002. The Rainbow vent fluids $36^{\circ} 14 ' \mathrm{~N}$, MAR: the influence of ultramafic rocks and phase separation on trace metal content in Mid-Atlantic Ridge hydrothermal fluids. Chemical Geology, 184(1-2), 37-48.

Fouquet, Y., Eissen, J.P., Ondréas, H., Barriga, F.J.A.S., Batiza, R., Danyushevsky, L., 1998. Extensive volcaniclastic deposits at the Mid Atlantic ridge axis: results of deep-water basaltic explosive volcanic activity? Terra Nova, 10, 280-286.

Feely, R.A., Gendron, J.F., Baker, E.T., Lebon, G.T., 1994. Hydrothermal plumes along the East Pacific Rise, $8^{\circ} 40$ to $11^{\circ} 50 \mathrm{~N}$ : Particle distribution and composition. Earth and Planetary Science Letters, 128, 19-36.

Fung, C.N., Lam, J.C.W., Zheng, G.J., Connell, D.W., Monirith, I., Tanabe, S., Richardson, B.J., Lam, P.K.S., 2004. Mussel-based monitoring of trace metal and organic contaminants along the east cost of China using Perna viridis and Mytilus edulis. Environmental Pollution, 127(2), 203-216.

Geret, F., Rousse, N., Riso, R., Sarradin, P-M., Cosson, R.P., 1998. Metal compartmentalization and metallothionein isoforms in mussels from the Mid-Atlantic Ridge: preliminary approach to the fluidorganism relationship. Cahiers de Biologie Marine, 39, 291-293.

Geret, F., 2000. Synthèse de métallothionéines chez deux bivalves (l'huître et la moule) en réponse à une contamination métallique par la voie directe et par la voie trophique. Ph.D. thesis, Université de Nantes.

Goldberg, E.D., Bowen, V.T., Farrington, J.W., Harwey, G., Martin, J.H., Parker, P.L., Risebrough, R.W., Robertson, W., Schneider, E., Gamble, E., 1978. The Mussel Watch. Environmental Conservation, 5, 101-125.

Kadar, E., Costa, V., Martins, I., Serrao Santos, R., Powell, J.J., 2005. Enrichment in trace metals (Al, $\mathrm{Mn}, \mathrm{Co}, \mathrm{Cu}, \mathrm{Mo}, \mathrm{Cd}, \mathrm{Fe}, \mathrm{Zn}, \mathrm{Pb}$ and $\mathrm{Hg}$ ) of macro-invertebrate habitats at hydrothermal vents along the Mid-atlantic Ridge. Hydrobiologia, 548, 191-205.

Kalpaxis, D.L., Theos, C., Xaplanteri, M.A., Dinos, G.P., 2004. Biomonitoring of Gulf of Patras, N. Peloponnesus, Greece. Application of a biomarker suite including evaluation of translation efficiency in Mytilus galloprovincialis cells. Environmental Research, 94, 211-220.

Kim, E.S., Kim, S.H., Kim, K.T., 1991. Elemental compositions of animals from hydrothermal vents and coldwater seeps. Ocean Resarch, 13(2), 1-9.

Langston, W.J., Bebianno, M.J., 1998. Metal Metabolism in Aquatic Environments. Chapman and Hall, London.

Langston, W.J., Bebianno, M.J., Burt, G.R., 1998. Metal handling strategies in molluscs. In: Langston, W.J., Bebianno, M.J. (Eds.). Metal Metabolism in Aquatic Environments, Chapman and Hall, London, 220-283 pp.

Lauenstein, G.G., Daskalakis, K.D., 1998. US long-term coastal contaminant temporal trends determined from molluscs monitoring programs, 1965-1993. Marine Pollution Bulletin, 37(1-2), 6-13.

Legendre, P., Legendre, L., 1998. Numerical ecology. Elsevier, Amsterdam, $2^{\text {nd }}$ engl. ed.

Le Bris, N., Sarradin, P-M., Caprais, J-C., 2003. Contrasted sulphide chemistries in the environment of $13^{\circ} \mathrm{N}$ EPR vent fauna. Deep-Sea Research (Part I), 50(6), 737-747.

Michard, G., Albarede, F., Michard, A., Minster, J-F., Charlou, J-L., Tan, N., 1984. Chemistry of solutions from the $13^{\circ} \mathrm{N}$ East Pacific Rise hydrothermal site. Earth and Planetary Science Letters, 67, 297-307.

Neff, J.M., 2002. Bioaccumulation in marine organisms. Elsevier.

Ondreas, H., Fouquet, Y., Voisset, M., Radford-Knoery, J., 1997. Detailed study of three continuous segments of the Mid-Atlantic Ridge, south of the Azores $\left(37^{\circ} \mathrm{N}\right.$ to $\left.38^{\circ} 30^{\prime} \mathrm{N}\right)$, using acoustic imaging coupled with submersible observations. Marine Geophysical Researches, 19, 231-255.

Phillips, D.J.H., 1977. The use of biological indicator organisms to monitor trace metal pollution in marine and estuarine environments: a review. Environmental Pollution, 13, 181-217. 
Phillips, D.J.H., 1985. Organochlorines and trace metals in green-lipped mussels Perna viridis from Hong Kong waters: a test of indicator ability. Marine Ecology-Progress Series, 21, 251-258.

Rainbow, P.S., 1995. Biomonitoring of heavy metal availability in the marine environment. Marine Pollution Bulletin, 31, 183-192.

Roesijadi, G., Crecelius, E.A., 1984. Elemental composition of the hydrothermal vent clam Calyptogena magnifica from the East Pacific Rise. Marine Biology, 83, 155-161.

Roesijadi, G., Young, J.S., Crecelius, E.A., Thomas, L.E., 1985. Distribution of trace metals in the hydrothermal vent clam, Calyptogena magnifica. Bulletin of the Biological Society of Washington, 6, 311-324.

Rousse, N., Boulègue, J., Cosson, R.P., Fiala-Médioni, A., 1998. Bioaccumulation des métaux chez le Mytilidae hydrothermal Bathymodiolus sp. de la Ride Médio-Atlantique. Oceanologica Acta, 21(4), 597-607.

Rousse, N., 1999. La bioaccumulation des métaux et les procédés de détoxication chez le mollusque bivalve symbiotique dépendant de la chimiosynthèse, Bathymodiolus sp. Ph.D. thesis, Université P.\&M. Curie, Paris.

Ruelas-Inzunza, J., Soto, L.A., Pàez-Osuna, F., 2003. Heavy-metal accumulation in the hydrothermal vent clam Vesicomya gigas from Guaymas Basin, Gulf of California. Deep-Sea Research (Part I), 50, 757-761.

Smith, D.R., Flegal, A.R., 1989. Elemental concentrations of hydrothermal vent organisms from the Galapagos Rift. Marine Biology, 102, 127-133.

Szefer, P., Kim, B.B., Kim, C.K., Kim, E.H., Lee, C.B., 2004. Distribution and co-associations of trace elements in soft tissue and byssus of Mytilus galloprovincialis relative to the surrounding seawater and suspended matter of the Southern part of the Korean Peninsula. Environmental Pollution, 129, 209228.

Trefry, J.H., Trocine, R.P., 1985. Iron and copper enrichment of suspended particles from an active hydrothermal plumes along the mid atlantic ridge. Geophysical Research Letters, 12(8), 506-509.

Tunnicliffe, V., 1991. The biology of hydrothermal vents: ecology and evolution. Oceanography and Marine Biology: an Annual Review, 29, 319-407.

Van Dover, C.L., Desbruyères, D., Segonzac, M., Comtet, T., Saldanha, L., Fiala-Médioni, A., Langmuir, C., 1996. Biology of the Lucky Strike hydrothermal field. Deep Sea Research (Part I), 43, 1509-1529.

Ventox. 2003. Deep-sea hydrothermal vents: a natural pollution laboratory. EVK3 CT 1999. Final report.

Von Damm, K.L., 1990. Seafloor hydrothermal activity: black smoker chemistry and chimneys. Annual Revue of Earth and Planetary Science, 18, 173-204.

Von Damm, K.L., 1995. Controls on the chemistry and temporal variability of seafloor hydrothermal fluids. In: Humphris, S.E., Zierenberg, R.A., Mullineaux, L.S., Thomson, R.E. (Eds.). Seafloor Hydrothermal Systems: Physical, Chemical, Biological and Geological Interactions, Geophysical Monograph 91, The American Geophysical Union, Washington, DC, 222-247 pp.

Wang, W.X., 2002. Interactions of trace metals and different marine food chains. Marine.EcologyProgress Series, 243, 295-309.

Zar, J.H., 1999. Biostatistical analysis. Prentice Hall, London, $4^{\text {th }}$ ed. 
Table 1 : Mean levels and standard deviation of metals in tissues of the vent mussel Bathymodiolus azoricus collected at three fields (five sites) on the Mid Atlantic Ridge-Azores Triple Junction. For each line, similar letters indicate no statistical difference among tissues $(p>0.05)$. Levels are expressed as $\mu \mathrm{g} \cdot \mathrm{g}^{-1}$ dry weight of soft tissue. A8 and A10 (Menez Gwen field), BA and ET (Bairro Alto and Eiffel Tower - Lucky Strike field).

\begin{tabular}{|c|c|c|c|c|c|c|c|c|c|c|}
\hline \multirow[b]{3}{*}{ GILLS } & \multicolumn{4}{|c|}{ MENEZ GWEN } & \multicolumn{4}{|c|}{ LUCKY STRIKE } & \multicolumn{2}{|l|}{ RAINBOW } \\
\hline & \multicolumn{2}{|c|}{ A8 } & \multicolumn{2}{|l|}{ A10 } & \multirow{2}{*}{\multicolumn{2}{|c|}{$\mathrm{BA}$}} & \multirow{2}{*}{\multicolumn{2}{|c|}{ ET }} & & \\
\hline & & & & & & & & & & \\
\hline $\mathrm{Ag}$ & $4.5 \pm 1.2$ & $\mathrm{a}$ & $1.9 \pm 1.3$ & $b$ & $5.2 \pm 1.3$ & a & $2.1 \pm 0.7$ & $b$ & $1.8 \pm 1.1$ & $b$ \\
\hline $\mathrm{Cd}$ & $7.4 \pm 2.5$ & c & $3.2 \pm 1.0$ & $d$ & $47.2 \pm 9.8$ & a & $17.6 \pm 2.2$ & $\mathrm{~b}$ & $1.8 \pm 0.7$ & e \\
\hline $\mathrm{Cu}$ & $57 \pm 12$ & $\mathrm{~b}$ & $130 \pm 82$ & a & $80 \pm 21$ & $a b$ & $109 \pm 69$ & $\mathrm{a}$ & $52 \pm 27$ & $\mathrm{~b}$ \\
\hline $\mathrm{Fe}$ & $183 \pm 46$ & c & $206 \pm 45$ & bc & $361 \pm 185$ & $a b$ & $488 \pm 570$ & $a b$ & $2066 \pm 956$ & $\mathrm{a}$ \\
\hline $\mathrm{Mn}$ & $6.3 \pm 0.8$ & $\mathrm{a}$ & $4.8 \pm 0.7$ & $b$ & $9.5 \pm 6.5$ & a & $7.2 \pm 1.7$ & $\mathrm{a}$ & $9.1 \pm 2.6$ & $\mathrm{a}$ \\
\hline $\mathrm{Zn}$ & $168 \pm 33$ & c & $197 \pm 57$ & bc & $1977 \pm 605$ & a & $768 \pm 578$ & $a b$ & $106 \pm 46$ & $\mathrm{c}$ \\
\hline \multicolumn{11}{|c|}{ MANTLE } \\
\hline $\mathrm{Ag}$ & $0.7 \pm 0.3$ & $a$ & $0.5 \pm 0.3$ & $a b$ & $0.8 \pm 0.3$ & $\mathrm{a}$ & $0.4 \pm 0.1$ & bc & $0.1 \pm 0.1$ & c \\
\hline $\mathrm{Cd}$ & $0.5 \pm 0.3$ & $\mathrm{bc}$ & $0.5 \pm 0.4$ & bc & $2.4 \pm 1.2$ & a & $1.2 \pm 0.6$ & $a b$ & $0.04 \pm 0.03$ & c \\
\hline $\mathrm{Cu}$ & $9 \pm 4$ & bc & $81 \pm 76$ & $\mathrm{a}$ & $15 \pm 6$ & $a b c$ & $28 \pm 27$ & $a b$ & $1 \pm 1$ & c \\
\hline $\mathrm{Fe}$ & $28 \pm 35$ & $\mathrm{C}$ & $40 \pm 47$ & bc & $229 \pm 113$ & a & $141 \pm 74$ & $a b$ & $186 \pm 94$ & $a b$ \\
\hline $\mathrm{Mn}$ & $3.0 \pm 0.7$ & bc & $2.4 \pm 1.8$ & c & $6.4 \pm 2.4$ & $\mathrm{a}$ & $5.5 \pm 1.1$ & $a b$ & $8.4 \pm 2.5$ & a \\
\hline $\mathrm{Zn}$ & $46 \pm 13$ & $\mathrm{~cd}$ & $100 \pm 63$ & $a b$ & $145 \pm 67$ & a & $69 \pm 27$ & bc & $28 \pm 8$ & d \\
\hline \multirow{2}{*}{\multicolumn{11}{|c|}{$\begin{array}{c}\text { DIGESTIVE } \\
\text { GLAND }\end{array}$}} \\
\hline & & & & & & & & & & \\
\hline $\mathrm{Ag}$ & $0.9 \pm 0.3$ & a & $0.4 \pm 0.1$ & b & & & $0.5 \pm 0.2$ & $\mathrm{~b}$ & $0.5 \pm 0.2$ & $\mathrm{~b}$ \\
\hline $\mathrm{Cd}$ & $4.0 \pm 1.3$ & $\mathrm{a}$ & $2.3 \pm 0.5$ & b & & & $4.5 \pm 2.1$ & a & $1.5 \pm 1.0$ & $b$ \\
\hline $\mathrm{Cu}$ & $30 \pm 15$ & b & $172 \pm 81$ & a & & & $48 \pm 27$ & b & $11 \pm 10$ & $\mathrm{C}$ \\
\hline $\mathrm{Fe}$ & $198 \pm 91$ & c & $200 \pm 60$ & c & & & $919 \pm 699$ & $b$ & $1854 \pm 1048$ & $\mathrm{a}$ \\
\hline $\mathrm{Mn}$ & $3.8 \pm 2.1$ & c & $2.1 \pm 0.6$ & d & & & $5.4 \pm 1.6$ & b & $8.1 \pm 1.9$ & $\mathrm{a}$ \\
\hline $\mathrm{Zn}$ & $82 \pm 42$ & $\mathrm{~b}$ & $111 \pm 49$ & $b$ & & & $276 \pm 81$ & $\mathrm{a}$ & $45 \pm 12$ & $c$ \\
\hline
\end{tabular}


Table 2 : Mean levels and standard deviation of amounts (expressed as percentages) of metals associated with insoluble compounds in the tissues of vent mussels collected at the studied Azores Triple Junction sites. A8 and A10 (Menez Gwen field), BA and ET (Bairro Alto and Eiffel Tower - Lucky Strike field). B. t.: Bathymodiolus thermophilus collected during the HOPE99 cruise at the East Pacific Rise (EPR) $9^{\circ} \mathrm{N}$ vent site (Cosson, unpublished data), M. edulis: Mytilus edulis, from Bay of Bourgneuf and Normandy shellfish farms used as control in laboratory experiments, except for Ag data obtained from Ag-exposed mussels (Geret, 2000). ** : levels were too low to allow the determination of $\mathrm{Ag}$ levels in soluble and/or insoluble fractions.

\begin{tabular}{|c|c|c|c|c|c|c|c|c|c|c|c|c|c|c|c|}
\hline & \multicolumn{13}{|c|}{ Bathymodiolus azoricus } & \multirow{2}{*}{$\begin{array}{l}\text { B. } t . \\
\text { EPR }\end{array}$} & \multirow{3}{*}{$\begin{array}{c}\text { M. edulis } \\
\text { Geret } \\
2000\end{array}$} \\
\hline & \multicolumn{6}{|c|}{ MENEZ GWEN } & \multicolumn{6}{|c|}{ LUCKY STRIKE } & \multirow[t]{2}{*}{ RAINBOW } & & \\
\hline & & A8 & & & A1 & & & $\mathrm{BA}$ & & & ET & & & $9 \mathrm{~N}$ & \\
\hline \multicolumn{16}{|c|}{ GILLS } \\
\hline $\mathrm{Ag}$ & 27 & \pm & 6 & 24 & \pm & 14 & 43 & \pm 1 & 10 & 43 & \pm & 15 & $31 \pm 25$ & 89 & $33 / 13 /$ ** \\
\hline $\mathrm{Cd}$ & 57 & \pm & 5 & 47 & \pm & 7 & 80 & \pm & 7 & 73 & \pm & 7 & $47 \pm 18$ & 43 & $17 / * \star / 24$ \\
\hline $\mathrm{Cu}$ & 64 & \pm & 5 & 76 & \pm & 9 & 80 & \pm & 5 & 86 & \pm & 4 & $65 \pm 10$ & 91 & $54 / 38$ / 44 \\
\hline $\mathrm{Fe}$ & 82 & \pm & 4 & 82 & \pm & 4 & 74 & \pm & 8 & 79 & \pm & 8 & $75 \pm 5$ & & \\
\hline $\mathrm{Mn}$ & 61 & \pm & 3 & 68 & \pm & 5 & 86 & \pm & 5 & 71 & \pm & 5 & $68 \pm 7$ & & \\
\hline $\mathrm{Zn}$ & 45 & \pm & 8 & 45 & \pm & 13 & 94 & \pm & 2 & 84 & \pm & 7 & $37 \pm 15$ & 38 & 48 / 55 / 47 \\
\hline \multicolumn{16}{|c|}{ MANTLE } \\
\hline $\mathrm{Ag}$ & 31 & \pm & 16 & 38 & \pm & 26 & 36 & \pm & 7 & 50 & & 14 & $22 \pm 15$ & 91 & $24 / 26 /$ ** \\
\hline $\mathrm{Cd}$ & 61 & \pm & 18 & 85 & \pm & 14 & 57 & & 11 & 42 & & 22 & $67 \pm 25$ & 45 & $\star \star / * * / * \star$ \\
\hline $\mathrm{Cu}$ & 52 & \pm & 17 & 89 & \pm & 6 & 66 & \pm 1 & 12 & 69 & \pm & 14 & $34 \pm 24$ & 89 & $60 / 55 / 29$ \\
\hline $\mathrm{Fe}$ & 58 & \pm & 24 & 79 & \pm & 17 & 68 & \pm 1 & 17 & 68 & \pm & 14 & $80 \pm 7$ & & \\
\hline $\mathrm{Mn}$ & 49 & \pm & 7 & 45 & \pm & 17 & 62 & \pm & 7 & 50 & \pm & 3 & $57 \pm 9$ & & \\
\hline $\mathrm{Zn}$ & 66 & \pm & 9 & 82 & \pm & 7 & 81 & \pm & 8 & 68 & & 11 & $48 \pm 10$ & 59 & 42 / 35 / 51 \\
\hline \multicolumn{16}{|c|}{ DIGESTIVE } \\
\hline $\mathrm{Ag}$ & 54 & \pm & 19 & 41 & \pm & 19 & & & & 80 & & 14 & $24 \pm 22$ & & $18 / 23 / 24$ \\
\hline $\mathrm{Cd}$ & 79 & \pm & 8 & 80 & \pm & 11 & & & & 94 & \pm & 5 & $48 \pm 23$ & & $22 / 18 / 15$ \\
\hline $\mathrm{Cu}$ & 88 & \pm & 7 & 98 & \pm & 1 & & & & 95 & \pm & 5 & $68 \pm 18$ & & $32 / 29$ / 09 \\
\hline $\mathrm{Fe}$ & 96 & \pm & 3 & 98 & \pm & 1 & & & & 95 & \pm & 6 & $77 \pm 11$ & & \\
\hline $\mathrm{Mn}$ & 87 & \pm & 8 & 89 & \pm & 5 & & & & 92 & \pm & 5 & $61 \pm 18$ & & \\
\hline $\mathrm{Zn}$ & 92 & \pm & 6 & 96 & \pm & 2 & & & & 97 & \pm & 2 & $61 \pm 20$ & & 32 / 33 / 44 \\
\hline
\end{tabular}

Table 3 : End-member concentrations in the Mid Atlantic Ridge-Azores Triple Junction (Menez Gwen, Lucky Strike and Rainbow), East Pacific Rise (EPR) and Guaymas Basin vent fluids. Adapted from Charlou et al., 2002; Cosson, 1996; Douville et al., 2002; LeBris et al., 2003; VonDamm, 1995.

\begin{tabular}{lccccc}
\hline Site & Menez Gwen & Lucky Strike & Rainbow & EPR 13N & Guaymas \\
\hline $\mathrm{T}\left({ }^{\circ} \mathrm{C}\right)$ & $265-284$ & $152-333$ & $360-365$ & $230-359$ & $100-315$ \\
$\mathrm{Fe}(\mathrm{mM})$ & $0.024-0.028$ & $0.03-0.86$ & 24 & $0.6-10.8$ & $0.017-0.18$ \\
$\mathrm{Cu}(\mu \mathrm{M})$ & $0.6-2.9$ & $1-26$ & 140 & & \\
$\mathrm{Zn}(\mu \mathrm{M})$ & $2.4-5.1$ & $5-58$ & 160 & $2-102$ & \\
$\mathrm{Cd}(\mathrm{nM})$ & $9-12$ & $18-79$ & 130 & $55-70$ & \\
$\mathrm{~Pb}(\mathrm{nM})$ & $21-56$ & $35-130$ & 148 & $14-135$ & \\
\hline
\end{tabular}




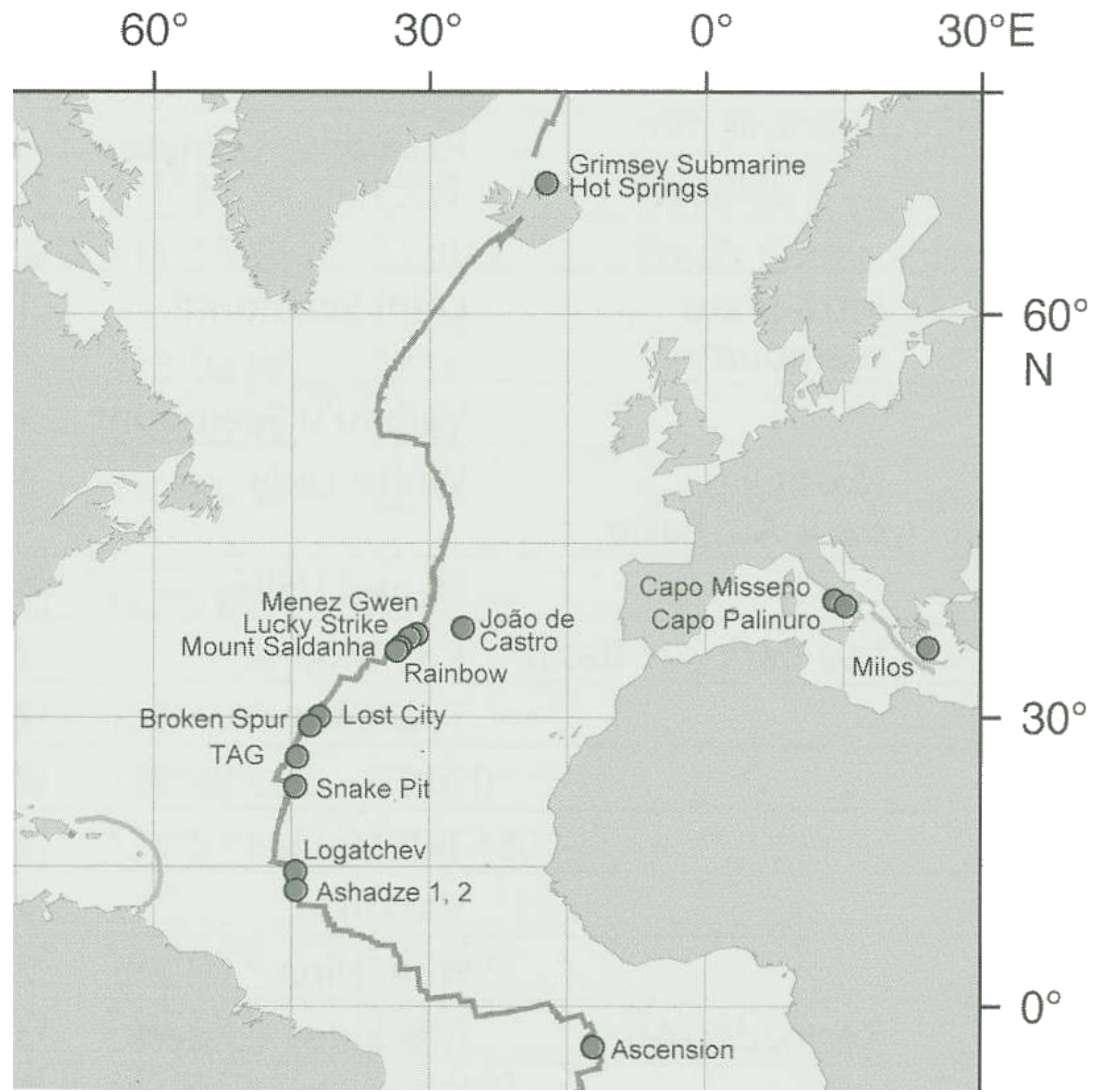

Figure 1: Location of the vent fields on the Mid-Atlantic Ridge (adapted from Desbruyères et al., 2006). 


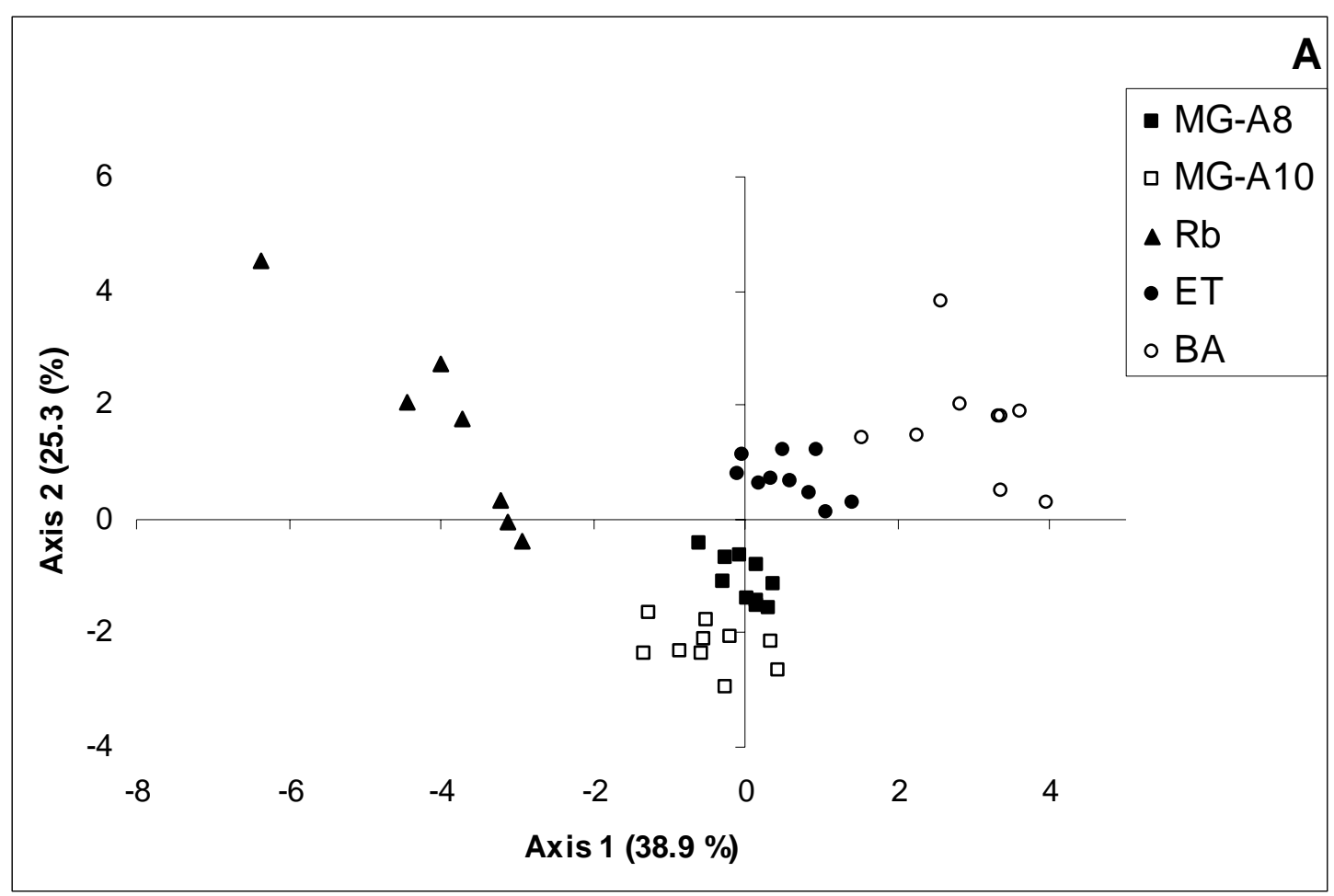

GILLS

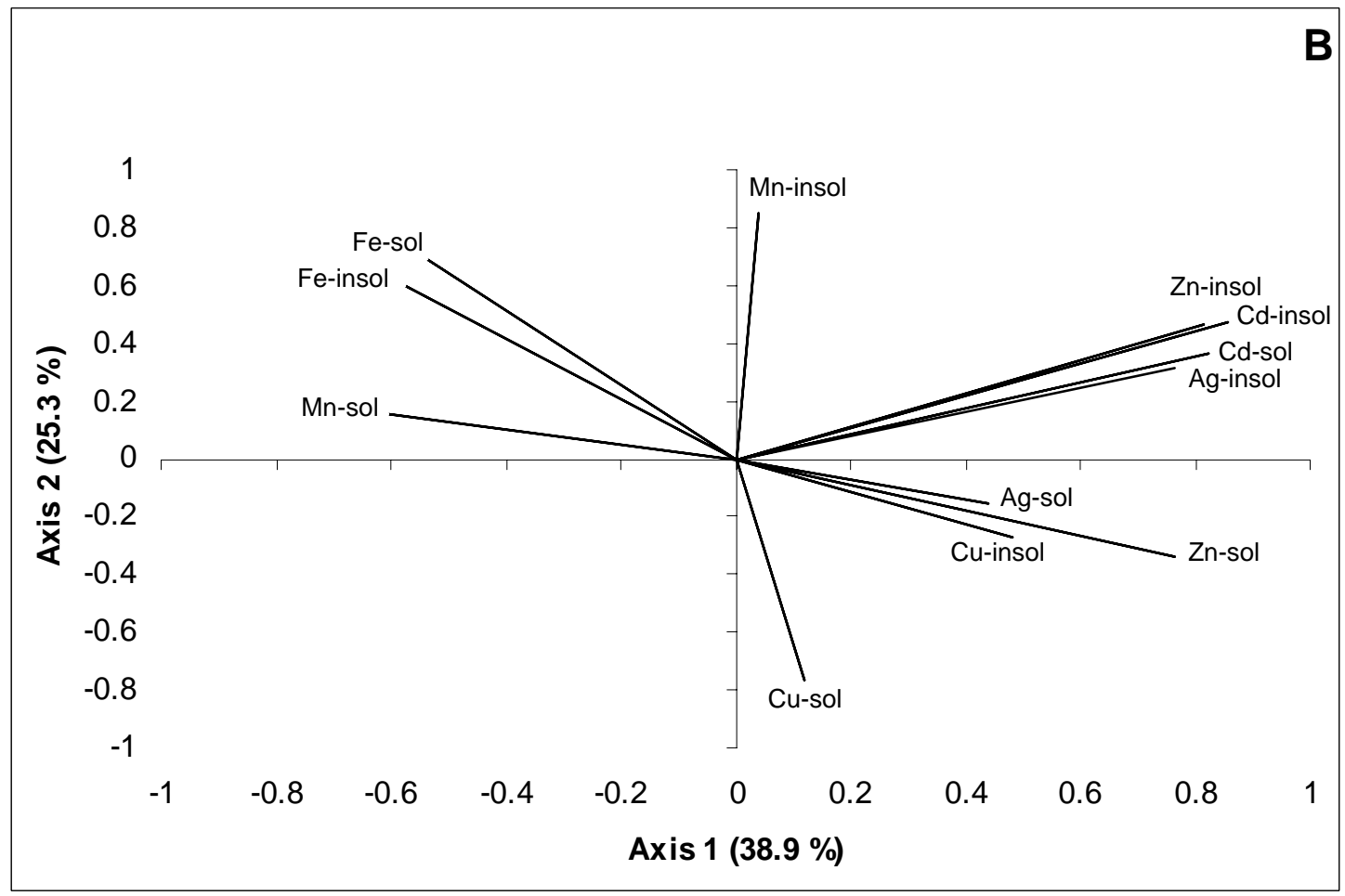

Figure 2 : First plane principal component analysis (PCA) of mussels based on metal levels in soluble and insoluble fractions of the gills. (A) individual scores. (B) descriptor scores. MG-A8 and MG-A10 (Menez Gwen field), BA and ET (Bairro Alto and Eiffel Tower - Lucky Strike field), Rb (Rainbow field). 


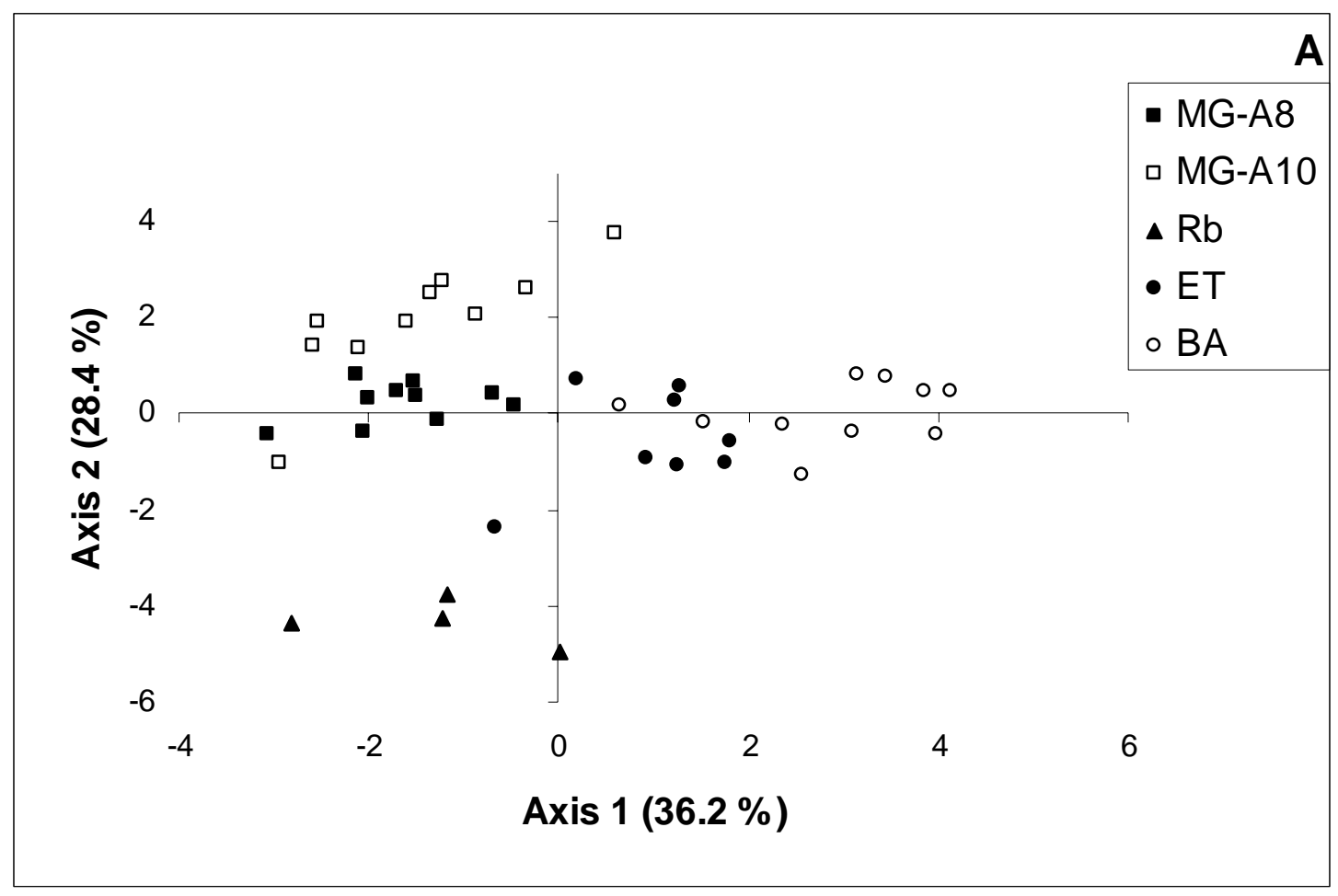

MANTLE

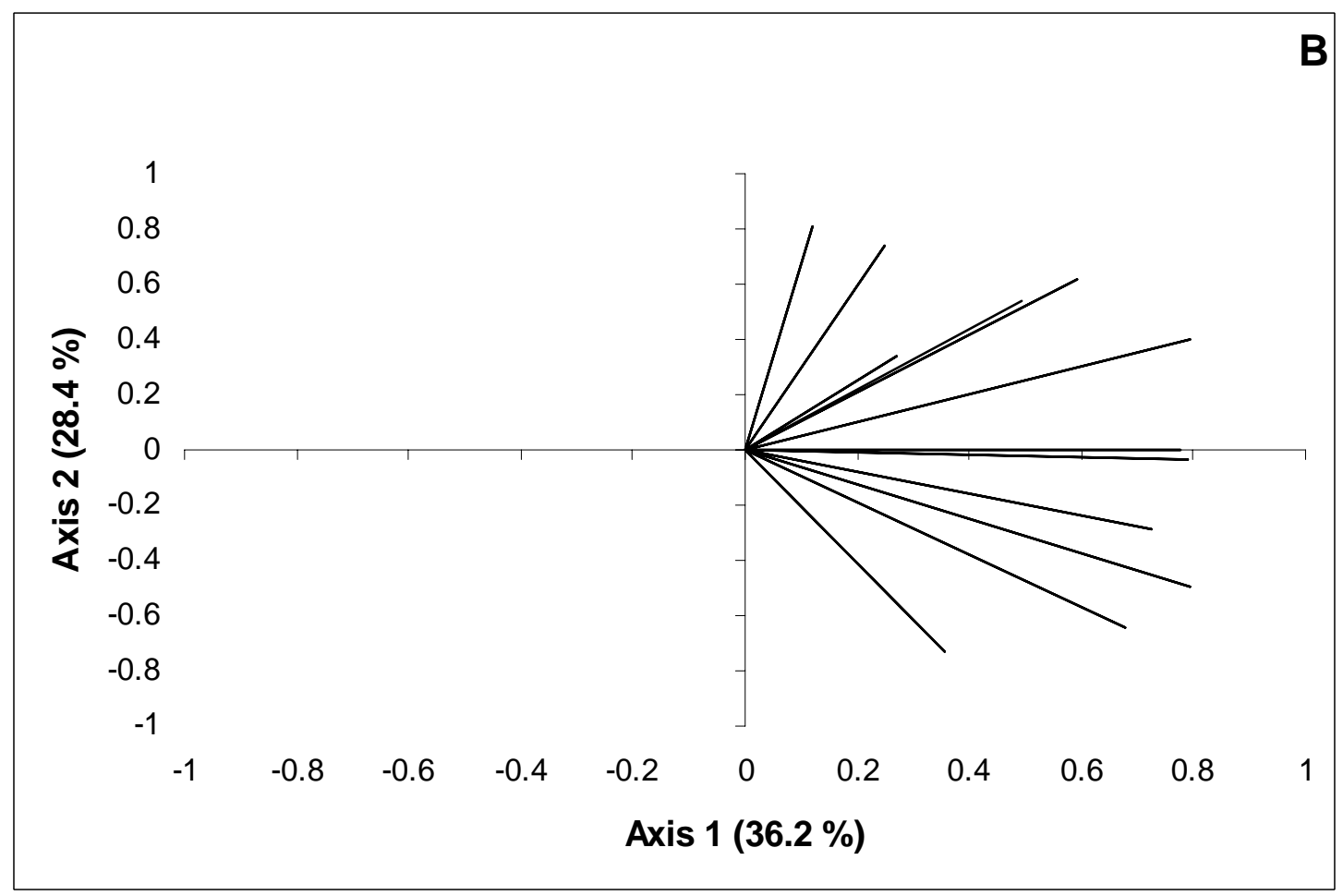

Figure 3 : First plane principal component analysis (PCA) of mussels based on metal levels in soluble and insoluble fractions of the mantle. (A) individual scores. (B) descriptor scores. MG-A8 and MG-A10 (Menez Gwen field), BA and ET (Bairro Alto and Eiffel Tower - Lucky Strike field), Rb (Rainbow field). 


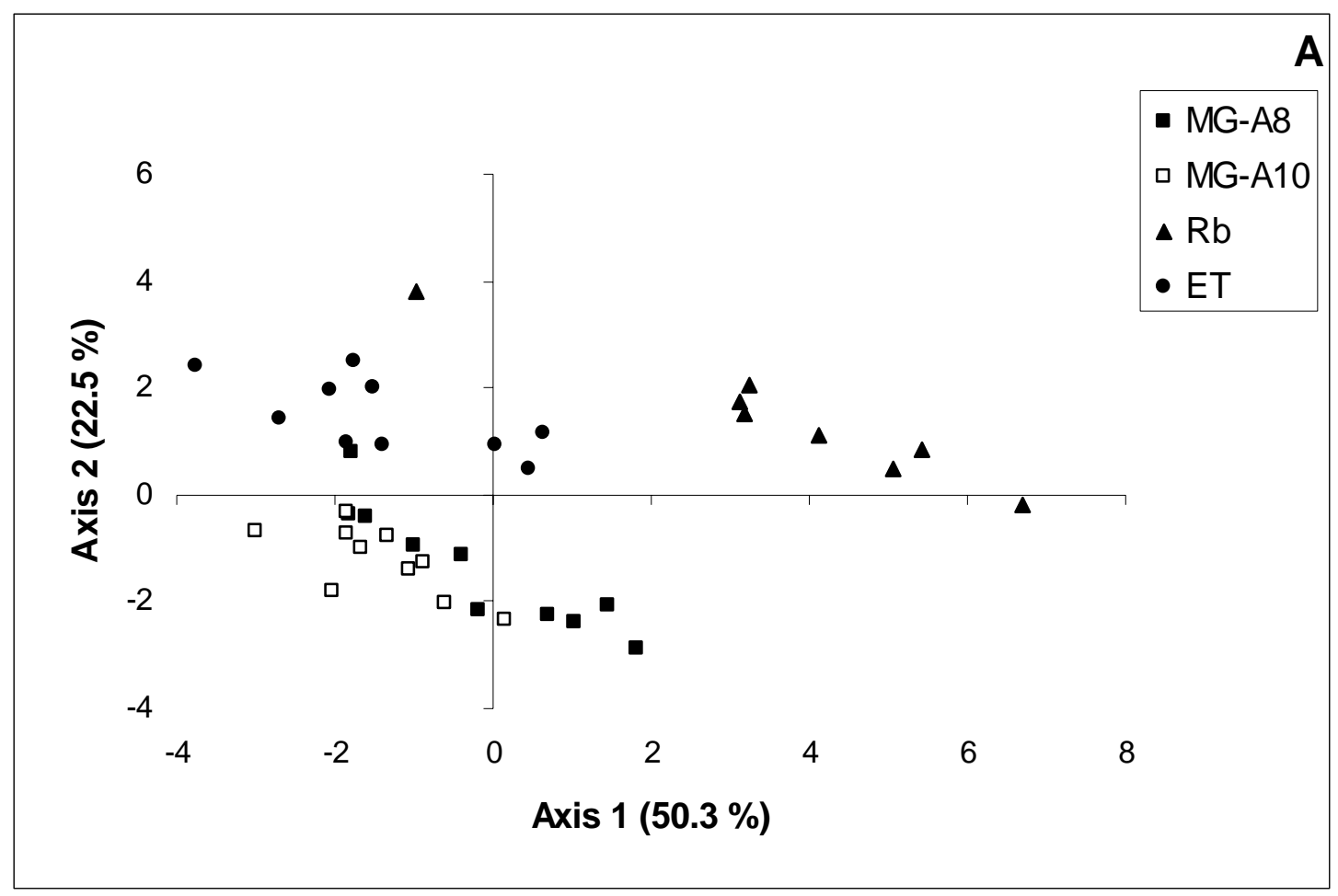

DIGESTIVE

GLAND

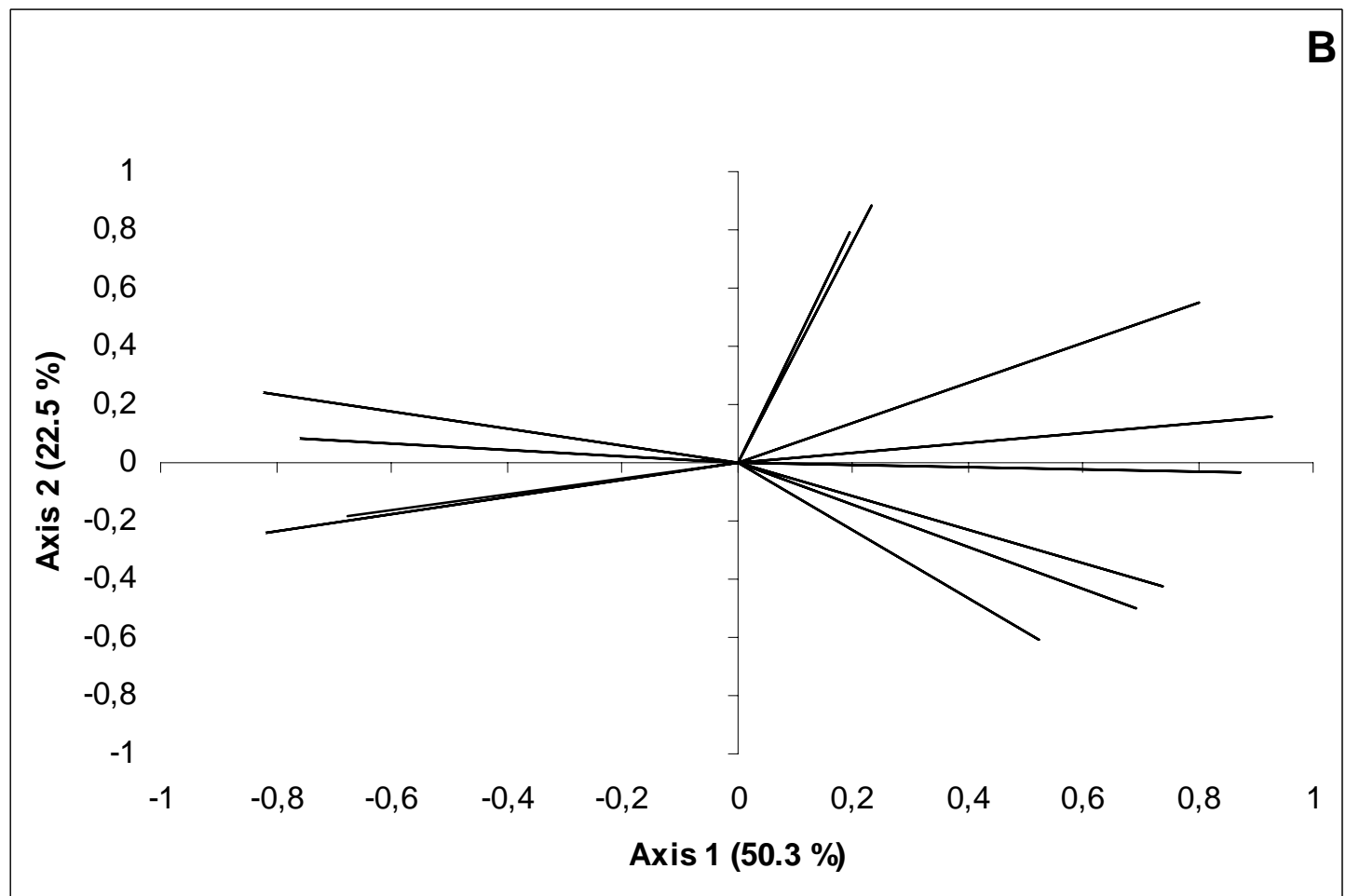

Figure 4 : First plane principal component analysis (PCA) of mussels based on metal levels in soluble and insoluble fractions of the digestive gland. (A) individual scores. (B) descriptor scores. MG-A8 and MG-A10 (Menez Gwen field), BA and ET (Bairro Alto and Eiffel Tower - Lucky Strike field), Rb (Rainbow field). 
A

SILVER

Calyptogena

magnifica

thermophilus Gills

Bathymodiolus Gills

azoricus

Mantle

CADMIUM

Calyptogena

magnifica

Gills

Vesicomya

gigas

Bathymodiolus

thermophilus

Bathymodiolus

azoricus

COPPER

Calyptogena

magnifica Mantle

Vesicomya Gills

gigas Mantle

Bathymodiolus Gills

thermophilus Mantle

Bathymodiolus Gills

azoricus Mantle

MANGANESE

Calyptogena

magnifica

Gills

Vesicomya

gigas

Mantle

Mantle

Bathymodiolus Gills

thermophilus Mantle

Bathymodiolus Gills 


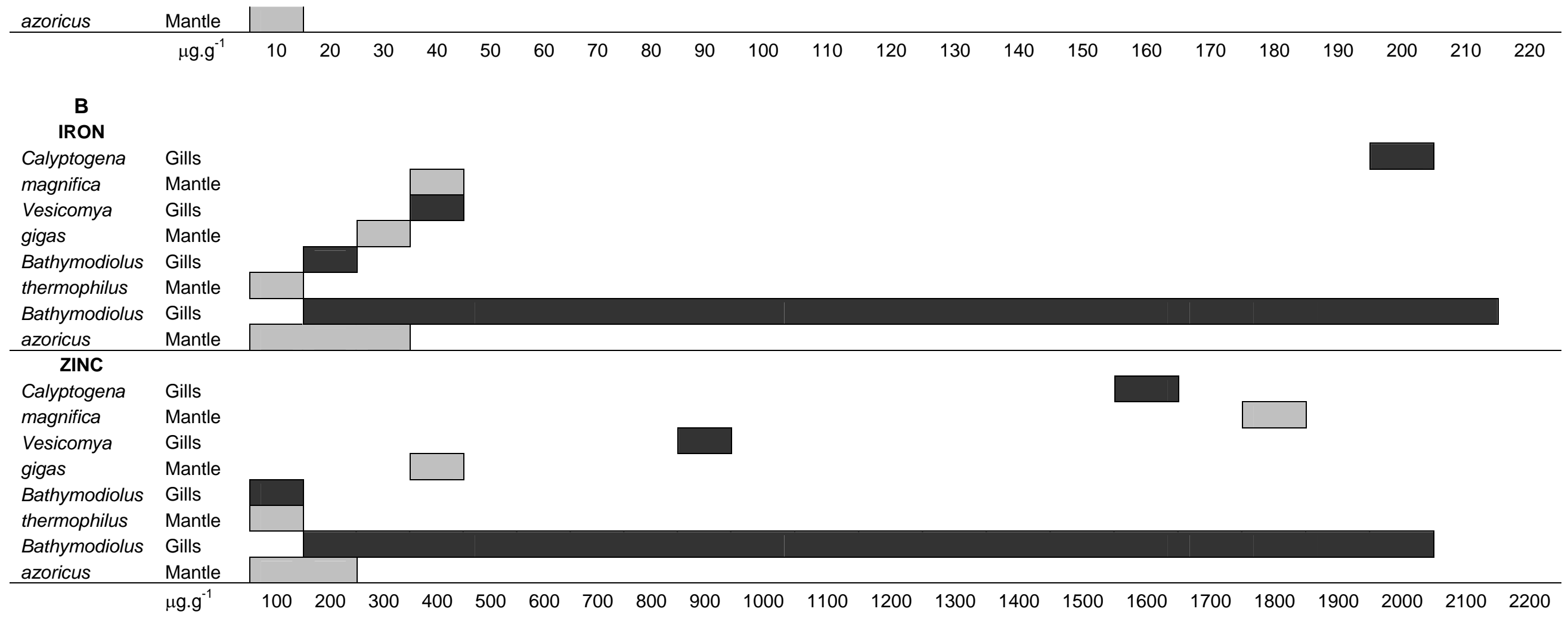

Figure 5 : Comparison of Bathymodiolus azoricus gill and mantle metal level range with the average levels of metals observed in corresponding organs within bivalves from the East Pacific Rise hydrothermal vents. A: Ag, Cd, Cu, Mn levels, scale 0-220 $\mu \mathrm{g} . \mathrm{g}^{-1} \mathrm{dw}$. B: Fe, Zn levels, scale 0-2200 $\mu \mathrm{g} . \mathrm{g}^{-1} \mathrm{dw}$. Calyptogena magnifica (Roesijadi and Crecelius, 1984; Roesijadi et al., 1985; Cosson-Mannevy et al., 1988); Vesicomya gigas (Ruelas-Inzunza et al.,2003); Bathymodiolus thermophilus (Rousse, 1999). 